University of Nebraska - Lincoln

DigitalCommons@University of Nebraska - Lincoln

Publications, Agencies and Staff of the U.S.

Department of Commerce

U.S. Department of Commerce

2010

\title{
Dreissena and the disappearance of the spring phytoplankton bloom in Lake Michigan
}

\author{
Henry A. Vanderploeg \\ Great Lakes Environmental Research Laboratory, henry.vanderploeg@noaa.gov \\ James R. Liebig \\ Great Lakes Environmental Research Laboratory, jim.liebig@noaa.gov \\ Thomas F. Nalepa \\ Great Lakes Environmental Research Laboratory, thomas.nalepa@noaa.gov \\ Gary L. Fahnenstiel \\ Great Lakes Environmental Research Laboratory, gary.fahnenstiel@noaa.gov \\ Steven A. Pothoven \\ Great Lakes Environmental Research Laboratory, steve.pothoven@noaa.gov
}

Follow this and additional works at: https://digitalcommons.unl.edu/usdeptcommercepub

Part of the Environmental Sciences Commons

\footnotetext{
Vanderploeg, Henry A.; Liebig, James R.; Nalepa, Thomas F.; Fahnenstiel, Gary L.; and Pothoven, Steven A., "Dreissena and the disappearance of the spring phytoplankton bloom in Lake Michigan" (2010).

Publications, Agencies and Staff of the U.S. Department of Commerce. 401.

https://digitalcommons.unl.edu/usdeptcommercepub/401
}

This Article is brought to you for free and open access by the U.S. Department of Commerce at DigitalCommons@University of Nebraska - Lincoln. It has been accepted for inclusion in Publications, Agencies and Staff of the U.S. Department of Commerce by an authorized administrator of DigitalCommons@University of Nebraska - Lincoln. 


\title{
Dreissena and the disappearance of the spring phytoplankton bloom in Lake Michigan
}

\author{
Henry A. Vanderploeg a,*, James R. Liebig a, Thomas F. Nalepa ${ }^{\text {a }}$, Gary L. Fahnenstiel ${ }^{\text {b }}$, Steven A. Pothoven ${ }^{\text {b }}$ \\ a National Oceanic and Atmospheric Administration, Great Lakes Environmental Research Laboratory, 4840 S. State Road., Ann Arbor, MI 48108, USA \\ ${ }^{\mathrm{b}}$ Great Lakes Environmental Research Laboratory, Lake Michigan Field Station, 1431 Beach St., Muskegon, MI 49441, USA
}

\section{A R T I C L E I N F O}

\section{Article history:}

Received 14 September 2009

Accepted 21 April 2010

Communicated by Hunter Carrick

\section{Index words:}

Quagga mussel

Zebra mussel

Nearshore phosphorus shunt

Mid-depth phosphorus sink

\begin{abstract}
A B S T R A C T
We determined the clearance rates of the profunda morph of the quagga mussel (Dreissena bugensis) using seston and Cryptomonas ozolini, a high-quality algal food, for the temperature range $1-7^{\circ} \mathrm{C}$, which is the full temperature range this morph is likely to experience during isothermal conditions or in the hypolimnion of deep lakes. Experiments at $3{ }^{\circ} \mathrm{C}$ with the shallow-water morph of the quagga and the zebra mussel provided very similar results. The clearance rates were combined with dreissenid abundance in 0-30 m, 30-50 m, 50-90 m, and >90 m depth zones of the southern basin of Lake Michigan to calculate a maximum (using Cryptomonas) and minimum (using seston) fraction of the water column cleared (FC) per day in the different depth zones at $3{ }^{\circ} \mathrm{C}$ to determine dreissenid impact on the spring phytoplankton bloom from 1994 to 2008. Starting in 2003 or 2004 with the replacement of zebra mussels by quagga mussels in shallow water and expansion of quagga mussel biomass in deep water, FC began to exceed likely phytoplankton growth in the 30-50 m zone. In 2007-2008, FC greatly exceeded likely phytoplankton growth by a factor of about 5 in the 30- to 50-m depth zone, where dreissenids were extremely abundant. Low FC in the offshore region led to the hypothesis of a mid-depth carbon (C) and phosphorous (P) sink caused by mussel uptake of seston-associated $C$ and $P$ that affected not only the mid-depth region, but also the offshore region "downstream" of the mid-depth zone.
\end{abstract}

Published by Elsevier B.V.

\section{Introduction}

Profound water-quality impacts of zebra and quagga mussels (collectively dreissenids) have long been recognized in shallow, nearshore areas, where they have been typically found in high abundance (e.g., Vanderploeg et al., 2002; Hecky et al., 2004). For example, dreissenid mussel filtering activities in bays and shallow areas have led to decreased chlorophyll $a$ concentrations and increased water clarity (physical ecosystem engineering) in spring, and the promotion of harmful algal blooms (HABs) in summer consisting primarily of the toxic colonial cyanobacterium Microcystis through selective rejection of the large toxic colonies of this species (Vanderploeg et al., 2001, 2002, 2009). In addition to these filtering and physical engineering impacts, dreissenids have played a fundamental role in the re-engineering of nutrient cycling. Because of homeostatic nutrient excretion, in phosphorus-rich systems, dreissenids would tend to increase $\mathrm{P}$ availability as soluble $\mathrm{P}$ (and decrease $\mathrm{N}$ :P ratios); however, in P-poor systems, dreissenids excrete little $\mathrm{P}$, so as to maintain constant concentrations in their tissues (Vanderploeg et al., 2002). Thus, depending on nutrient loading and mussel density, the dreissenid effects on nutrient cycling will vary across systems.

\footnotetext{
* Corresponding author.

E-mail addresses: henry.vanderploeg@noaa.gov (H.A. Vanderploeg), jim.liebig@noaa.gov (J.R. Liebig), tom.nalepa@noaa.gov (T.F. Nalepa), gary.fahnenstiel@noaa.gov (G.L. Fahnenstiel), steve.pothoven@noaa.gov (S.A. Pothoven)
}

Nutrient availability in turn can affect algal community composition, growth rate, and production (e.g. Vanderploeg et al., 2002).

Observed shifts in nutrients and production in the nearshore region can also affect offshore regions. Hecky et al. (2004) hypothesized that the collective impact of nearshore engineering of dreissenids has led to a "nearshore phosphorus shunt" retaining $\mathrm{P}$ (and C) at the expense of offshore areas. According to a series of hypotheses, $\mathrm{P}$ (both soluble and particulate) that would have moved from tributaries through the nearshore and then offshore is captured and held by the nearshore assemblage of dreissenids and their associated benthic community .

As a result of mussel feeding, excretion (soluble and particulate nutrients), and physical engineering (Vanderploeg et al., 2002) activities, both pelagic and benthic lower food web components (microzooplankton, mesozooplankton, and benthic invertebrates) have been appreciably affected (Fahnenstiel et al., 1995; Maclsaac, 1996; Lavrentyev et al., 1995; Vanderploeg et al., 2002). As a consequence, fish that depend on these energy pathways have also been negatively impacted (Strayer et al., 2004). During the proliferation of zebra mussels, food web impacts were mainly confined to bays or nearshore areas, with offshore impacts, other than the loss of Diporeia, being mostly equivocal (e.g., Vanderploeg et al., 2002).

Recently, however, extreme declines in chlorophyll $a$ and increases in water clarity are apparent in deeper waters of the Great Lakes (e.g., Fahnenstiel et al., 2010; Kerfoot et al., 2010). In Lake Michigan, Fahnenstiel et al. (2010) document a major decrease in chlorophyll that occurred during the winter-spring transition with loss of the spring 
phytoplankton bloom. In addition, there was a shift in phytoplankton composition with loss of large diatoms and an increase in colonial cyanobacteria (Fahnenstiel et al., 2010). It appeared that many of these offshore ecosystem changes occurred subsequent to the recent explosion and expansion of the quagga mussel "profunda" morph (deep-water phenotype) into deep waters.

The winter-spring transition is an important time for phytoplankton production and phytoplankton-mussel interactions in Lake Michigan, and dynamics during this period affect production throughout the year. Vanderploeg et al. (2002) argued that mussel filtering during the winter-spring transition (isothermal period) would be the most important time for impacting phytoplankton in deepwater systems like Lake Michigan, because the dreissenids would have access to the full water column during this well-mixed period, whereas during the stratified period, reduced vertical mixing would limit access to phytoplankton in the water column. Strong support for a well-mixed water column is given by a number of recent studies, particularly those associated with the Episodic Events Great Lakes Experiment (EEGLE), that clearly demonstrated that properties like chlorophyll concentrations are constant from top to bottom and that currents have the same direction and speed from top to bottom, thus implying a mixed condition (e.g. Fahnenstiel et al., 2000; Beletsky et al., 2003; Rao et al., 2004; Vanderploeg et al., 2007; Kerfoot et al., 2008, 2010).

After autumn turnover-typically occurring at $5{ }^{\circ} \mathrm{C}$ in Decemberisothermal conditions begin to prevail (e.g., Brooks and Torke, 1977). The intense winds at this time tend to promote complete mixing even before the water cools to the temperature of maximum density, $4^{\circ} \mathrm{C}$. Both water temperature and light decrease together until the winter solstice (e.g., Brooks and Torke, 1977; Scavia and Fahnenstiel, 1987; Vanderploeg et al., 2007). After the winter solstice, water temperature continues to decrease slowly until April reaching a typical minimum of $2{ }^{\circ} \mathrm{C}$ in offshore waters (e.g., Brooks and Torke, 1977; Vanderploeg et al., 2007), but solar radiation and photoperiod slowly increase. Until recently, depth-integrated chlorophyll concentration increased steadily with increasing light availability throughout the winterspring transition, reaching maximum yearly concentration in late spring before stratification or about the same time (Brooks and Torke, 1977; Scavia and Fahnenstiel, 1987; Fahnenstiel et al., 2010). Much of the time during the isothermal period, lake temperature hovers near $3-4{ }^{\circ} \mathrm{C}$. In summer, dreissenids in the hypolimnion would typically be exposed to temperatures around $4-5^{\circ} \mathrm{C}$.

There are four hypotheses for the recent offshore decrease in the spring phytoplankton concentration: (1) the direct impact of mussel filtering as they move into deeper water, (2) sequestering of nutrients by the nearshore shunt, (3) a decrease in P loading over time, and (4) sequestering $P$ by the mussels or community associated with them in deep water. Of particular concern here is the first hypothesis, since mussel filtering has an immediate direct impact on phytoplankton mortality. Two major necessities for evaluating the role of mussel filtering on phytoplankton concentration are: (1) specifying mussel clearance rates at low temperatures during the winter-spring transition and in the hypolimnion during summer, and (2) specifying some appropriate measure of population abundance from which to project the impact of clearance rates. Complicating the first necessity is the very important effect of food quality, which can be more important than temperature (Vanderploeg et al., 2009).

Unfortunately, there is almost no information on dreissenid feeding at low temperatures, that is, temperatures below $8{ }^{\circ} \mathrm{C}$ (Reeders and Bij DeVaate, 1990; Vanderploeg et al., 2009). Also, many investigators report mussel abundance only as numerical density, which is problematic in that mussel clearance varies with mussel size (e.g., Kryger and Riisgard, 1988). To help gain insight into these hypotheses, particularly the first, we determined the clearance rates of dreissenid mussels at low temperatures $\left(1-7^{\circ} \mathrm{C}\right)$. To deal with the problem of food quality we examined the feeding rate response of mussels on natural seston as well as on an ideal food that was representative of the assemblage before expansion of the mussels into deep water. This information was combined with recently determined depth distribution of mussel densities, lengths, and weights in the southern basin of Lake Michigan (Nalepa et al., 2010) to project a filtering impact to different depth regions in 1994-2008.

\section{Methods}

\section{The study site, collection methods, and handling}

Mussels and water were collected in Lake Michigan at M45 (43 $11.29^{\circ} \mathrm{N}, 8625.92^{\circ} \mathrm{W}$ ) a site on the $45-\mathrm{m}$ deep depth contour approximately 4 nautical miles west of Muskegon, MI, on four dates during April to September 2008 (Fig. 1). This site was chosen because it has been a part of both pelagic and benthic monitoring programs (Vanderploeg et al., 2007; Nalepa et al., 2006) and displayed increased mussel densities (Nalepa et al., 2006) and decreased chlorophyll $a$ (Chl), likely associated with the increase in mussels. All mussels at this site, as well as other sites in Lake Michigan, were the profunda morph of the quagga mussel ( $D$. bugensis) characterized by a long incurrent siphon and a modoliform shell (Nalepa et al., 2010).

Water and mussels were collected in the morning and transported to NOAA's Great Lakes Environmental Research Laboratory (GLERL) in Ann Arbor, MI, where they arrived by late afternoon for re-acclimation in preparation for the seston feeding experiments using methods similar to those of Vanderploeg et al. (2001, 2009). Mussels were collected by benthic sled, and immediately upon collection, were wrapped in moist paper towels and placed in a cooler. Ice or cold gel packs were placed above the mussels for transport to keep them near ambient, cool temperatures. Water was collected in a 30-L Niskin bottle, transferred into 25 -L carboys, and placed in coolers to maintain ambient temperature. During isothermal conditions, water was collected from the middle of the water column. During times the water column exhibited stratification, water was collected from the middle of the hypolimnion.

\section{Feeding experiment overview}

Two kinds of feeding experiments were conducted. The first used natural seston, that is, the water collected at M45 from April to November 2008 (Table 1). The second used cultured Cryptomonas ozolini, a highly desirable food (Vanderploeg et al., 2001, 2009) suspended in filtered $(0.2 \mu \mathrm{m})$ lake water. Cryptomonas and other cryptophytes are a common part of the phytoplankton assemblage during the winter spring transition (Bundy et al., 2005). Cryptomonas was presented at a chlorophyll concentration between 0.8 and $3.0 \mu \mathrm{g} \mathrm{L}^{-1}$ (Table 2), values that bracket those found during the winter-spring transition (Vanderploeg et al., 2007) before the massive expansion of dreissenids, and are below values that saturate feeding (Vanderploeg et al., 2001, 2009).

The usual premise of exploring the effect of temperature on clearance rate is that clearance rate is a function of filter area and of ciliary beat rate, which is a function of temperature (e.g., Kryger and Riisgard, 1988; Jones et al., 1992; Lei et al., 1996). It has been argued from extensive data on the marine mussel Mytilus edulis that mussel filter area approximates the "square law", which means that filter area is proportional to $L^{2}$, where $L$ is mussel length (e.g., Jones et al., 1992). Some results for dreissenid mussels appear to be consistent with this observation. Lei et al. (1996) observed that filter area in zebra mussels was proportional to $\mathrm{L}^{1.90}$. Mussel clearance has also been expressed on a per weight $(W)$ basis, which would be consistent with biomass varying with the cube of length. Jones et al. (1992) observed that clearance rate in the marine mussel Mytilus edulis was proportional to $W^{0.67}$ therefore, weight-specific rates, i.e., normalizing clearance rates to weight would imply that clearance rate per unit biomass would vary with $W^{-0.33}$. Likewise, Baldwin et al. (2002) reported that for the 


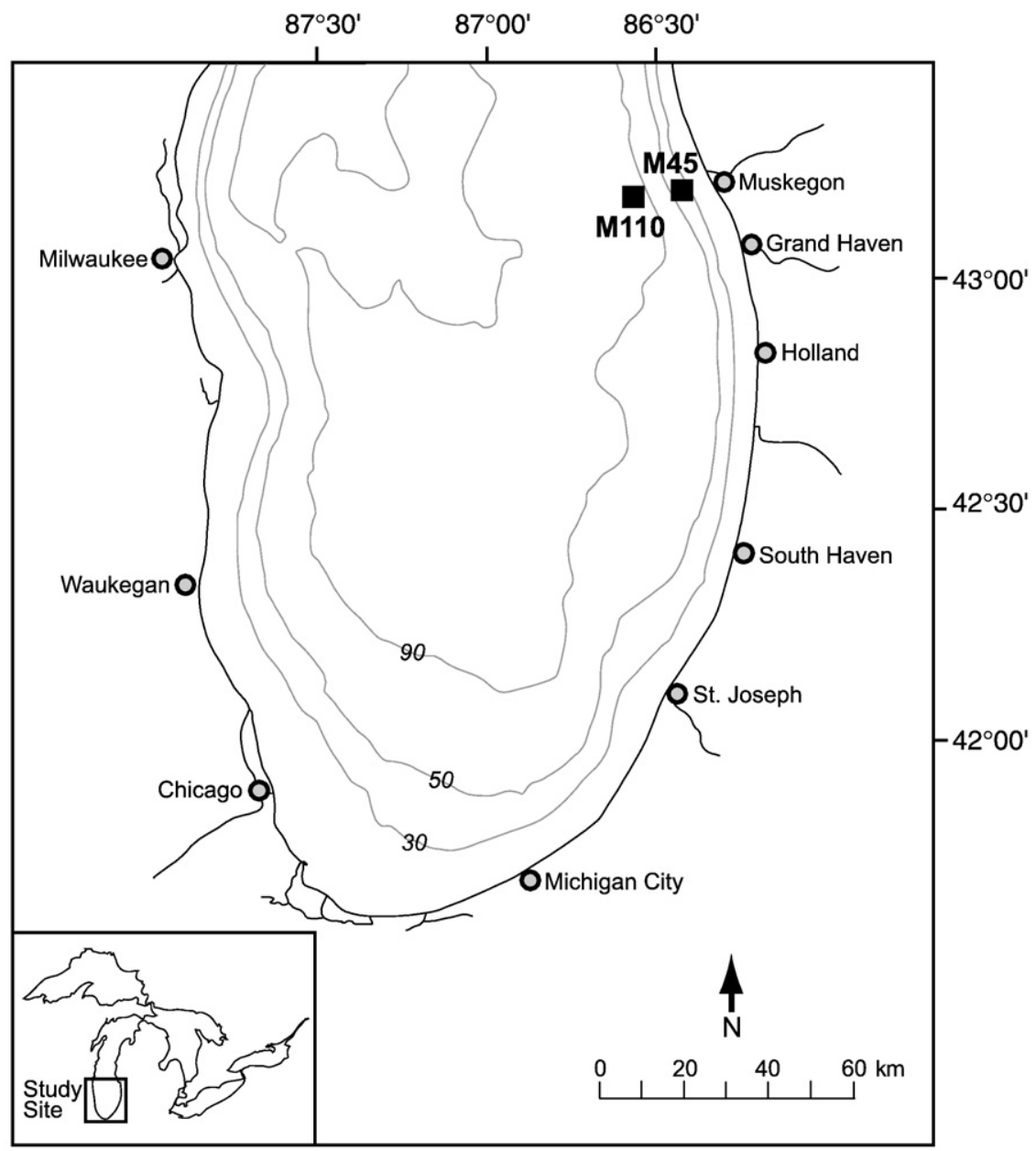

Fig. 1. Map of sampling locations near Muskegon, Michigan and depth contours of the southern basin of Lake Michigan.

shallow morph quagga mussels he used in his experiments, clearance rate varied according to $\mathrm{W}^{0.63}$. Thus, results of Lei et al. (1996) and Baldwin et al. (2002) would be approximately consistent with the square law. However, Kryger and Riisgard (1988) observed that clearance rate expressed on a per weight basis varied with $\mathrm{W}^{-0.12}$. Since we do not know how filter area varies with length or weight in profunda morph quagga mussels, we decided to use two approaches for expressing results. First, we determined the clearance rate of the mussels and normalized it to $L^{2}$, which we will call relative filter area (RFA). Second, we also normalized results to ash-free dry weight (AFDW). The latter approach is especially pertinent to available data in the literature, because dreissenid abundance is typically presented either as numerical density or biomass. AFDW of mussels was determined by length-weight regression of AFDW for animals collected at the same time and station as mussels (Nalepa et al.,

\section{Table 1}

Conditions during feeding experiments with natural seston from Lake Michigan $L=$ mean mussel length, $W=$ mean ash-free-dry weight, and $C(0)$ is mean initial chlorophyll concentration in experiments.

\begin{tabular}{|c|c|c|c|c|c|c|}
\hline \multirow[t]{2}{*}{ Experiment date } & \multirow{2}{*}{$\begin{array}{l}T \\
\left({ }^{\circ} \mathrm{C}\right)\end{array}$} & \multicolumn{2}{|l|}{ Mussel } & \multicolumn{3}{|c|}{$C(0)(\mu \mathrm{g} / \mathrm{L})$} \\
\hline & & $L(\mathrm{~mm})$ & $W(\mathrm{mg})$ & $>53 \mu \mathrm{m}$ & $<53 \mu \mathrm{m}$ & Total \\
\hline 9 April 2008 & 2.0 & 22.6 & 19.81 & 0.012 & 0.162 & 0.179 \\
\hline 1 May 2008 & 4.0 & 22.1 & 17.44 & 0.000 & 0.302 & 0.302 \\
\hline 13 August 2008 & 5.4 & 21.2 & 12.37 & 0.072 & 0.077 & 0.149 \\
\hline 5 September 2008 & 7.0 & 21.2 & 18.08 & 0.025 & 0.084 & 0.109 \\
\hline
\end{tabular}

2010) or direct measurement of the animals by weighing at $60{ }^{\circ} \mathrm{C}$ for $48 \mathrm{~h}$ followed by ashing at $550{ }^{\circ} \mathrm{C}$ (Nalepa et al., 2010).

Re-acclimation procedure for seston feeding experiments

Upon arrival at GLERL, the mussels and water were stored at ambient lake temperature and photoperiod, and $\sim 20-25$ mussels in the size range of $20-22 \mathrm{~mm}$ were selected for the feeding experiments. They were cleaned of debris and placed in a 30-L or 50-L aquarium filled with the lake water over night. The next morning, mussels were placed in a new aquarium with fresh water from the carboys for $\sim 2 \mathrm{~h}$ before being removed and used in the feeding experiment, again using fresh water from the carboys (Vanderploeg et al., 2001, 2009). The total reacclimation period lasted $\sim 17-18 \mathrm{~h}$. Water during the acclimation period was kept at ambient photoperiod and temperature in an incubator at a light intensity of $\sim 50 \mu \mathrm{mol}$ quanta $/ \mathrm{m}^{2} / \mathrm{s}$ during the day portion of the light cycle.

Feeding experiments with seston

The set-up of feeding experiments, experimental approach, and equations followed the standard methods described by Vanderploeg et al. (2001, 2009). Briefly the experimental set up consisted of four experimental beakers (with mussels) and two control beakers (without mussels) for which we measured $\mathrm{Chl}$ initially in each beaker, Chl in the water column at the end of the experiment, and $\mathrm{Chl}$ in the beakers at the end of the experiment after mixing up settled material, thus allowing a mass balance of mussel-induced changes to distinguish between what 
Table 2

Gross $(F)$ and net $\left(F_{A}\right)$ clearance rates of the profunda morph quagga mussel on large ( $\left.>53 \mu \mathrm{m}\right)$ and small $(<53 \mu \mathrm{m})$ size fractions of natural seston from the hypolimnion of the $45-\mathrm{m}$ depth station of Lake Michigan using the size-fractioned chlorophyll method. See Table 1 for details of mussel size and initial concentration of chlorophyll in the experiments.

\begin{tabular}{|c|c|c|c|c|c|c|c|}
\hline \multirow[t]{3}{*}{ Experiment date } & \multirow{3}{*}{$\begin{array}{l}T \\
\left({ }^{\circ} \mathrm{C}\right)\end{array}$} & \multicolumn{6}{|c|}{ Clearance rate $(\mathrm{ml} / \mathrm{mg} / \mathrm{h})$} \\
\hline & & \multicolumn{3}{|l|}{$\bar{F}$} & \multicolumn{3}{|l|}{$F_{A}$} \\
\hline & & $>53 \mu \mathrm{m}$ & $<53 \mu \mathrm{m}$ & Total & $>53 \mu \mathrm{m}$ & $<53 \mu \mathrm{m}$ & Total \\
\hline 9 April 2008 & 2.0 & $9.49 \pm 2.07$ & $4.10 \pm 0.86$ & $4.53 \pm 0.88$ & $0.57 \pm 1.48$ & $5.20 \pm 0.47$ & $4.88 \pm 0.37$ \\
\hline 1 May 2008 & 4.0 & - & $7.30 \pm 0.93$ & $7.30 \pm 0.93$ & - & $7.40 \pm 0.90$ & $7.40 \pm 0.90$ \\
\hline 13 August 2008 & 5.4 & $15.52 \pm 1.65$ & $11.95 \pm 1.57$ & $13.38 \pm 1.45$ & $19.23 \pm 1.55$ & $13.68 \pm 1.48$ & $15.87 \pm 1.36$ \\
\hline 5 September 2008 & 7.0 & $6.20 \pm 0.84$ & $8.33 \pm 0.84$ & $7.92 \pm 0.73$ & $5.81 \pm 0.96$ & $7.44 \pm 0.64$ & $7.08 \pm 0.67$ \\
\hline
\end{tabular}

Chl was filtered (gross feeding) and what was assimilated (net feeding) as explained in Vanderploeg et al. (2001, 2009). Experiments, depending on water temperature, lasted $2-3 \mathrm{~h}$, and gentle bubbling through a pipette kept water circulating in the 2-L control and 2-L experimental beakers with $4-5$ mussels typically in each beaker. Experiments were conducted in dim light $\left(\sim 8 \mu \mathrm{mol}\right.$ quanta $\left./ \mathrm{m}^{2} / \mathrm{s}\right)$ to limit algal growth. Under such conditions, experience showed we could expect 30-40\% of the seston to be removed, a fraction large enough to overcome errors associated with measurement of chlorophyll ( $<5 \% \mathrm{SE} /$ mean), differential algal growth between control and experimental beakers, sampling water (seston) from beakers, and differences in mussel feeding among containers.

We measured changes in Chl concentration in small $(<53 \mu \mathrm{m})$ and large $(>53 \mu \mathrm{m})$ size fractions, which allowed us to report clearance rates in each of the fractions and for total Chl. Historically, the large size fraction has been dominated by "net" diatoms such as Fragilaria, Synedra, Asterionella, and Aulacoseira (Vanderploeg et al., 1988; Bundy et al., 2005). Since we are concerned with potential impacts of mussels on the water column in the lake, we calculated a gross clearance rate $(F)$, the Chl removed from the beaker water column, and net clearance rate $\left(F_{\mathrm{A}}\right)$, the $\mathrm{Chl}$ assimilated, for each size fraction and for the total $\mathrm{Chl}$ filtered. Chlorophyll $a(\mathrm{Chl})$ was determined by filtering water through Whatman GF/F filters, extracting the filters in either $90 \%$ or $\mathrm{N}, \mathrm{N}$-dimethylformamide, and analyzing the extract fluorometrically (Strickland and Parsons, 1972; Speziale et al., 1984).

\section{Feeding experiments with Cryptomonas}

Experiments with Cryptomonas were conducted with the same mussels used in or collected for the experiments with seston but run within a few days to $\sim 1$ month after collection (Table 3 ) using the same experimental set up. On the day before the experiments, the mussels received an acclimation period, much like the experiments with seston, but to Cryptomonas.

We did two experiments with a group of smaller mussels (14 mm) run at the same time with the other larger (20-22 mm) mussels to see if they would give similar clearance rates as the larger mussels when expressed on a relative filter area (RFA) or weight basis. In addition to the Cryptomonas experiments with the profunda morph quagga mussels, we also did two low temperature experiments with the shallow morph quagga and one with the zebra mussel (Table 3 ) to see how they compared with the profunda morph. The shallow morph quagga mussels came from western Lake Erie from the 6-m depth contour near the mouth of the Raisin River. Zebra mussels were collected on rocks in the pool above Argo Dam (Ann Arbor, MI) on the Huron River.

In the laboratory, mussels were maintained on either Shellfish Diet 1800 (concentrated mixture of Isochrysis, Pavlova, Tetraselmis, and Thalassiosira weissflogii; Reed Mariculture, Campbell, Ca) or Cryptomonas. Cryptomonas was cultured on modified WC media at $20^{\circ} \mathrm{C}$ as described in Vanderploeg et al. $(2001,2009)$. On the day before the experiment, the Cryptomonas culture was cooled to the temperature used in the feeding experiments.

Because of the small size ( $8 \mu \mathrm{m}$ equivalent spherical diameter) of Cryptomonas, it was unnecessary to do size-fractioned Chl analyses. Because of its high digestibility, net and gross clearance rates were nearly identical, and we present results as net clearance rates.

\section{Projecting clearance rates to impacts in southern Lake Michigan}

To calculate potential mussel-induced mortality to phytoplankton and microzooplankton in Lake Michigan during the spring bloom, we determined the fraction of the water column cleared (FC) per day in different depth zones of the southern basin of the lake: $<30 \mathrm{~m}, 30-50 \mathrm{~m}$, 50-90 m, and >90 $\mathrm{m}$ for 1994-2008 for which Nalepa et al. (2010) determined mussel biomass and size distribution of mussels. We used the regression results for seston and for Cryptomonas (see below) at $3^{\circ} \mathrm{C}$, a temperature that typified the winter spring transition. Individual experiments at this time closely compared to the regression results and the seston for these experiments was also appropriate for the winterspring transition. Results are shown for 1998-2008, years for which there was significant biomass. We were also able assume during 1994-

Table 3

Summary of mussel species, morphotype, origin, mean length $(L)$, mean ash-free dry weight $(W)$, temperature $(T)$ history, initial chlorophyll concentration $(C(0))$, and net clearance rate $\left(F_{A}\right)$ per $L^{2}$ and per unit $W$ in experiments to examine the effect of low temperatures on clearance rates of quagga mussel profunda (Qp) and shallow (Qs) morphs and zebra mussels using cultured Cryptomonas ozolini. Origins of the mussels were the Huron River (HR), Lake Michigan (LM), and the western basin of Lake Erie (LE).

\begin{tabular}{|c|c|c|c|c|c|c|c|c|c|c|}
\hline \multirow{2}{*}{$\begin{array}{l}\text { Species/ } \\
\text { morph }\end{array}$} & \multirow[t]{2}{*}{ Origin } & \multirow{2}{*}{$\begin{array}{l}L \\
(\mathrm{~mm})\end{array}$} & \multirow{2}{*}{$\begin{array}{l}W \\
(\mathrm{mg})\end{array}$} & \multicolumn{2}{|l|}{ Collection } & \multicolumn{5}{|l|}{ Experiment } \\
\hline & & & & Date & $T\left({ }^{\circ} \mathrm{C}\right)$ & Date & $T\left({ }^{\circ} \mathrm{C}\right)$ & $C(0)(\mu \mathrm{g} / \mathrm{L})$ & $F_{A}\left(\mathrm{ml} / \mathrm{cm}^{2} / \mathrm{h}\right)$ & $F_{A}(\mathrm{ml} / \mathrm{mg} / \mathrm{h})$ \\
\hline Zebra & HR & 17.8 & 12.40 & 27 Mar 07 & 10 & 4 May 07 & 3.0 & 2.20 & $32.21 \pm 0.50$ & $8.34 \pm 0.72$ \\
\hline Qp & LM & 20.1 & 12.50 & 26 Apr 07 & 3 & 4 May 07 & 3.0 & 2.21 & $35.88 \pm 1.79$ & $11.58 \pm 0.48$ \\
\hline Qp & LM & 22.4 & 19.30 & 8 Apr 08 & 2 & 7 May 08 & 2.0 & 1.25 & $21.44 \pm 5.95$ & $5.54 \pm 1.55$ \\
\hline Qp & LM & 21.9 & 18.06 & 8 Apr 08 & 2 & 14 May 08 & 1.0 & 3.49 & $35.18 \pm 3.38$ & $9.23 \pm 0.95$ \\
\hline Qs & LE & 20.9 & & 22 Apr 08 & 10 & 8 May 08 & 2.0 & 3.26 & $39.18 \pm 1.46$ & - \\
\hline Qs & LE & 22.0 & & 22 Apr 08 & 10 & 13 May 08 & 1.0 & 2.49 & $39.37 \pm 3.50$ & - \\
\hline Qp & LM & 21.9 & 17.01 & 30 Apr 08 & 4 & 2 May 08 & 4.0 & 2.50 & $47.68 \pm 2.90$ & $13.40 \pm 1.14$ \\
\hline Qp & LM & 13.8 & 4.02 & 12 Aug 08 & 5.3 & 14 Aug 08 & 5.4 & 1.01 & $44.31 \pm 6.53$ & $20.88 \pm 3.23$ \\
\hline Qp & LM & 21.3 & 12.52 & 12 Aug 08 & 5.3 & 14 Aug 08 & 5.4 & 1.06 & $55.97 \pm 4.68$ & $20.26 \pm 1.48$ \\
\hline $\mathrm{Qp}$ & LM & 13.8 & 4.02 & 12 Aug 08 & 5.3 & 18 Aug 08 & 7.0 & 1.02 & $49.22 \pm 1.57$ & $23.10 \pm 0.75$ \\
\hline$Q p$ & LM & 21.3 & 12.52 & 12 Aug 08 & 5.3 & 18 Aug 08 & 7.0 & 1.02 & $72.35 \pm 1.68$ & $26.05 \pm 0.93$ \\
\hline
\end{tabular}


1998 that there was zero biomass at depths $>30 \mathrm{~m}$ because, although biomass was not determined, no mussels were found at these depths. Although mussels were first observed as early as 1992, they were not abundant enough in any depth zone to have any significant impact. Mussel distribution, although somewhat patchy, showed a general pattern clearly related to depth (Nalepa et al., 2010).

As a benchmark for impact, we compared FC to a phytoplankton average growth rate of 0.06 /day observed for isothermal conditions in Lakes Michigan, Erie, Huron, and Ontario (Fahnenstiel et al., 2000). Growth at this time is limited by light and nutrients and possibly temperature (Fahnenstiel et al., 2000). In all experiment performed across lakes, light saturated (maximum) growth rates were about 0.12 / day. As mussel populations increase to high levels, there would be an increase in water clarity in some systems such as Lake Michigan; therefore maximal values of 0.12 /day might be expected during later phases of mussel expansion depending on water column depth. However, this presupposes no nutrient limitation that could be co-occurring as nutrient loading decreases and mussels sequester nutrients (see below).

The fraction of the water column cleared per day (FC) was calculated as $F_{A} \times$ abundance per $\mathrm{m}^{2} \div$ mean water depth (m) in each zone. We also calculated a "whole-basin" estimate of FC for 2008 as the weighted sum of FC and relative water volumes in each zone. This approximation assumes instantaneous mixing across zones. Parameters used for these calculations are shown in Table 4. Mussel abundance was specified in two ways: (1) biomass (as AFDW) in each zone provided by Nalepa et al. (2010), and (2) total relative filter area in each zone generated from length frequency data on mussels and mussel numerical density also given by Nalepa et al. (2010).

\section{Correlations of changes in state variables with mussel impacts}

To examine whether recent changes in spring phytoplankton dynamics were related to mussel filtering, we looked for changes in average spring Chl and TP with FC in a subset of long-term data (Mida, 2010) that documented changes at M110 (Fig. 1) or at a station nearby. We examined the period 1994-2003 and 2007 and 2008, which covers the period during which mussels first started to appear to the present time. We did simple regressions of these data to document whether the changes during this period were significant. To explore potential connections of these changes with FC, we determined the association of the variables with FC (directly proportional to mussel biomass within a depth zone) in the different depth zones with linear regression. TP and Chl were ln-transformed, as the variables showed an exponential relationship to mussel biomass.

\section{Results}

\section{Clearance rates-seston experiments}

As expected from the perspective of food quality, the clearance rate responses of mussels to Cryptomonas and to seston were very

\section{Table 4}

Parameters used for calculation of the fraction of water cleared per day (FC) in each depth zone of the southern basin of Lake Michigan and the overall "basin-wide" estimate, which assumes complete and instantaneous mixing. Relative areas of each zone are taken from Nalepa et al. (2010). Relative volume of each zone is the weighted product of mean depth and relative area of each zone.

\begin{tabular}{llll}
\hline Depth zone $(\mathrm{m})$ & Mean depth & Relative area (\%) & Relative volume (\%) \\
\hline $0-30$ & 15 & 22.6 & 4.78 \\
$30-50$ & 40 & 11.6 & 6.54 \\
$50-90$ & 70 & 32.2 & 31.80 \\
$>90$ & 120 & 33.6 & 56.87 \\
\hline
\end{tabular}

different. Clearance rates on seston were lower than those at given temperature than for Cryptomonas whether expressed on a RFA or weight basis, except for the $2{ }^{\circ} \mathrm{C}$ results for clearance expressed on an RFA basis (Fig. 2). Chl concentration was extremely low in the seston experiments, particularly in the $>53 \mu \mathrm{m}$ size fraction. These total $\mathrm{Chl}$ values can be compared with historical values of $2-3 \mu \mathrm{g} / \mathrm{L}$ that occurred during the spring (Vanderploeg et al., 2007; Fahnenstiel et al., 2010; Mida, 2010), and the large size fraction was always an important component of the seston (e.g. Bundy et al., 2005). In the May experiment, $\mathrm{Chl}$ in the $>53 \mu \mathrm{m}$ size fraction was zero (Table 1 ).

The results for both gross $(F)$ and net clearance $\left(F_{A}\right)$ rates indicated that both large and small phytoplankton was cleared at about equal rates (Table 2). In the case of the April experiment, gross clearance rates in large and small size fractions were nearly identical, but net clearance rate on the $>53 \mu \mathrm{m}$ size fraction was extremely low and not significantly different from zero (Table 2). This is likely a result of particles produced from ingestion of small phytoplankton, thus masking results (e.g. Vanderploeg et al., 2001, 2009) for the > $53 \mu \mathrm{m}$ fraction, which had extremely low Chl to begin with (Table 1). Therefore, to characterize the overall response of the mussels to temperature, we reported $F_{A}$ for total Chl and plotted results in Fig. 2, expressed on per RFA and per AFDW bases.

The $F_{A}$ vs. temperature response, whether expressed on an AFDW or RFA basis, was dome shaped, showing a maximum value at $5.4^{\circ} \mathrm{C}$. Linear regressions for seston were not significant $(P>0.3$ in both cases). The low clearance rate at the highest temperature was partly
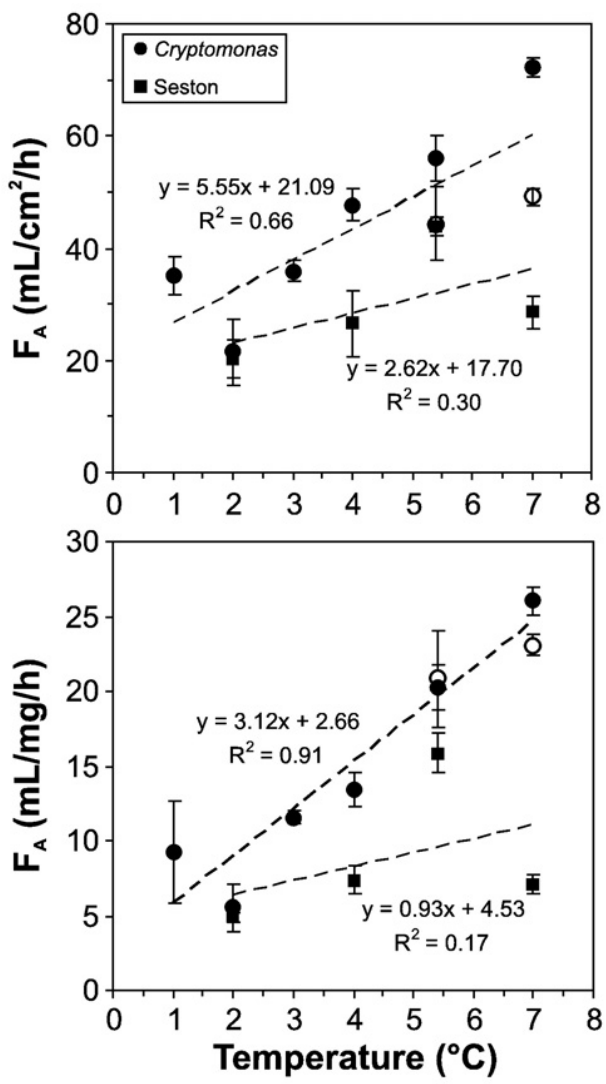

Fig. 2. Linear regressions of net clearance rate $\left(F_{A}\right)$ vs. temperature for Cryptomonas cultures and Lake Michigan seston: upper and lower panels show respectively results normalized to relative gill area and to ash-free dry weight. Closed and open symbols refer, respectively, to large $(20-22 \mathrm{~mm})$ and small $(14 \mathrm{~mm})$ mussels. Regressions for seston were not significant. Intercept \pm SE and slope \pm SE were: $21.09 \pm 7.82$ and $5.55 \pm 1.62$ for the relative gill area normalized regression; and $2.66 \pm 1.92$ and $3.12 \pm 0.40$ for the ashfree dry weight normalized regression. 
responsible for the poor fit of the linear regression (Fig. 2) at the higher temperatures Seston concentration was at its lowest point during this experiment (Table 1).

\section{Clearance rates-Cryptomonas experiments}

Clearance rate on Cryptomonas, whether normalized to RFA or weight: (1) generally increased with temperature, (2) was higher than observed for seston; and (3) showed fairly similar clearance rates at given temperature to the zebra mussel and shallow and profunda morphs of the quagga mussel (Tables 2 and 3, Fig. 2). The weight-normalized $F_{A}$ vs. temperature regression for the profunda morph quagga mussels (Fig. 1) gave a better result $\left(R^{2}=0.90\right.$, $P<<0.01)$ than that for RFA $\left(R^{2}=0.66, P=0.014\right)$. This resulted from the smaller mussels having a much lower clearance rate per RFA than the larger mussels (Fig. 2). Particularly striking was the very much higher rate seen for Cryptomonas than seston in the experiments at $7{ }^{\circ} \mathrm{C}$.

Although there were similarities in $F_{A}$ among species and morphs, there were differences. Whether expressed on a weight or RFA basis, the zebra mussels had a slightly lower filtering rate than the profunda morph of the quagga mussel for the $3{ }^{\circ} \mathrm{C}$ experiment of 4 May 2007. The quagga shallow morph had a considerably higher $F_{A}$ (normalized to RFA) at $2{ }^{\circ} \mathrm{C}$ than the quagga profunda morph; however, at $1{ }^{\circ} \mathrm{C}$ rates were very similar.
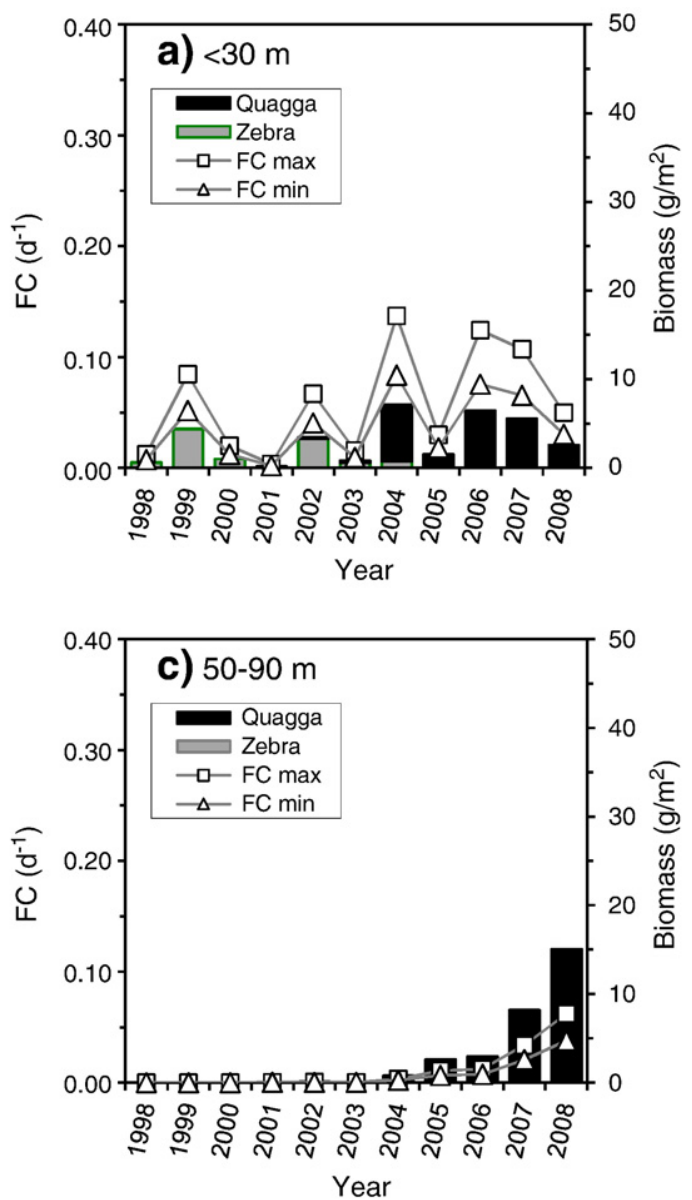

Impact of filtering to different depth zones of Lake Michigan

Filtering impacts (FC) of mussels (shown for $3{ }^{\circ} \mathrm{C}$ in Fig. 3) were a direct function of mussel biomass and increased in deeper water over time. From 1998 to 2003, FC was dominated by zebra mussels, which were restricted to depths $<50 \mathrm{~m}$. Starting in 2004 , filtering impact was dominated by quagga mussels that replaced zebra mussels in shallow water and progressively colonized deeper water. Highest FC was seen in the 30-50 m depth zone, and in 2007 and 2008, FC had increased appreciably in the $50-90 \mathrm{~m}$ zone so that FC was as high there as in shallow water $(<30 \mathrm{~m})$. Starting in 2004 , both maximum and minimum estimates of FC exceeded the benchmark estimate of algal growth of $0.06 /$ day, and by 2008 had reached values of more than 5 and 3 times the benchmark value for the $30-50 \mathrm{~m}$ depth zone. In 2008 , the maximal estimate of FC was approximately the same as the benchmark in the $50-90 \mathrm{~m}$ depth zone. Throughout much of the study period, maximal and minimal FC values were variable but not much different from the benchmark for algal growth rate in shallow water $(<30 \mathrm{~m})$. The FC estimate for the whole basin in 2008 was 0.044 /day, a value $74 \%$ of the benchmark growth rate. Calculations using RFA as a measure of abundance gave very similar results as those for AFDW.

Both Chl and TP decreased with about the same slope at M110 from 1994 to 2008, and the decreases were strongly correlated with FC in the 30-50 m (Tables 5 and 6). The regression for Chl vs. time regression was highly significant and for TP vs. time was significant.
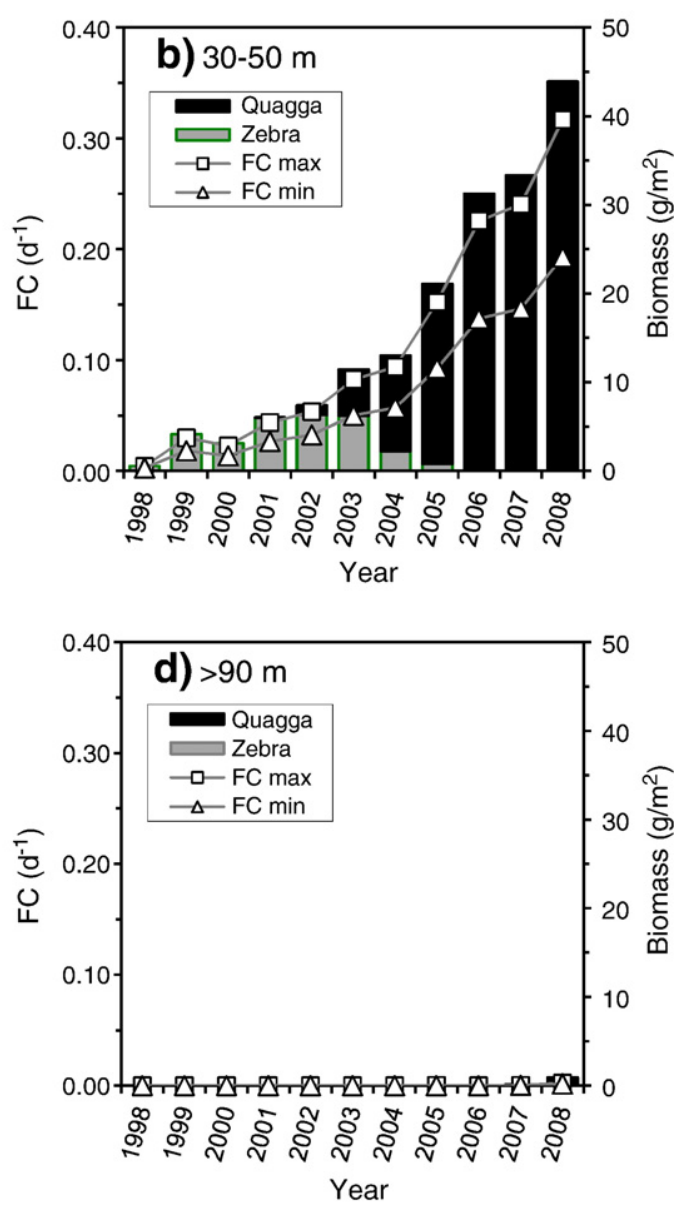

Fig. 3. Biomass of zebra and quagga mussels and fraction of water column cleared (FC) by zebra and quagga mussels in different depth zones of Lake Michigan at $3{ }^{\circ} \mathrm{C}$ using biomass reported by Nalepa et al. (2010): $<30 \mathrm{~m}$ (a), 30-50 m (b), 50-90 m (c), and >90 m (d). Maximum FC (FC max) refers to results determined for mussels feeding on Cryptomonas, an ideal food; and minimum FC (FC min) was the rate determined for natural lake seston severely depleted by the mussels. 
Chl at M110 was highly significantly negatively correlated with mussel FC in the 30-50 m depth zone and negatively correlated with FC in the 50-90 m depth zone. TP was negatively correlated with FC in the 30-50 m depth zone but not with FC in the 50-90 m depth zone.

\section{Discussion}

Mussel filtering at low temperatures

The experiments with Cryptomonas provided information for the first time of dreissenid mussel filtering throughout the temperature range $1-7^{\circ} \mathrm{C}$, which allow calculation of mussel feeding at temperatures found during winter and spring and in the hypolimnion during summer. Considering that the profunda quagga mussel morph has adapted to living in the deep portions of the Great Lakes, it is not surprising that appreciable filtering rates were observed. Interestingly, the limited comparative work we did suggest that clearance rates of zebra mussels and quagga shallow and profunda morphs were approximately the same, with zebra mussels having a slightly lower filtering rate on a per weight basis than the quagga profunda and shallow morphs. It would be interesting to see how filter area is related to size in the quagga morphs to explain why the smaller mussels had a lower clearance rate on an RFA basis. It is possible that smaller mussels were less healthy than larger mussels. This could have been reflected in a smaller weight/length ratio, and normalizing to weight would have corrected for their putative poor physiological status.

Previous comparative work $\left(21-23^{\circ} \mathrm{C}\right)$ on zebra and shallow morph quagga mussels suggested that mussels of a given length have similar clearance rates (Ackerman, 1999; Baldwin et al., 2002), but quagga mussel rates normalized to body mass were considerably lower since tissue weight of the quagga mussels was considerably higher (Baldwin et al., 2002). Our limited results are counter to these, and could possibly be related to differences associated with temperature or to biomass/length ratios of the mussels, which can vary by a factor of 4 depending on reproductive status and feeding conditions in the environment of origin (Vanderploeg et al., 2009).

Our clearance rates of dreissenids are considerably higher than those reported by Reeders and Bij DeVaate (1990), the only other study to report clearance rates of dreissenids at low temperatures. Food quality or quantity was a likely factor here. The clearance rate on a per capita basis at $3{ }^{\circ} \mathrm{C}$ observed by Reeders and Bij DeVaate (1990) was $11 \mathrm{~mL} / \mathrm{h}$ for 18 -mm zebra mussels on November seston from the Dutch lake, whereas our result (after conversion to an individual basis) was $103 \mathrm{~mL} / \mathrm{h}$ for the Huron River zebra mussels fed Cryptomonas. For 22-mm zebra mussels, clearance rate was about $18 \mathrm{~mL} / \mathrm{h}$ for November seston from the Dutch lake at $4{ }^{\circ} \mathrm{C}$, whereas rates of quagga profunda morph mussels of the same length were $129 \mathrm{~mL} / \mathrm{h}$ for Lake Michigan seston (1 May 2008) and $228 \mathrm{~mL} / \mathrm{h}$ for Cryptomonas. The seston concentration in this hypereutrophic system during November was $\sim 20 \mathrm{mg} / \mathrm{l}$, which is at least 10 times the recent historical levels found in the Great Lakes. One would expect this high seston level was far above the incipient limiting concentration. In summer experiments for which there was a large variation in seston concentration among experiments, Reeders and bij Vaate observed a large drop in clearance rate as seston concentrations increased

\section{Table 5}

Results for linear regressions of chlorophyll (Chl) and total phosphorus (TP) vs. time at station M110 using data reported by Mida et al. (2010) for winter-spring transition 1994-2003 and 2007 and 2008. Bolded $R^{2}$ values indicate significance at $P<0.05$ and bolded italicized $R^{2}$ values indicate significance at $P<0.01$ level.

\begin{tabular}{llllll}
\hline Variable & Station & $N$ & Intercept & Slope & $R^{2}$ \\
\hline Chl 1994-2008 & M110 & 11 & 3.21 & -0.170 & $\mathbf{0 . 7 3 9}$ \\
TP 1994-2008 & M110 & 11 & 6.36 & -0.182 & $\mathbf{0 . 4 0 3}$ \\
\hline
\end{tabular}

Table 6

Correlation coefficients for chlorophyll (Chl) and total phosphorous (TP) at M110 $(N=11)$ as related to FC in different depth zones using data of Mida et al. (2010) for the time period 1994-2003 and 2007 and 2008. Bolded and bolded italicized numbers are significant, respectively, at the $P<0.05$ and 0.01 levels.

\begin{tabular}{lll}
\hline Depth zone $(\mathrm{m})$ & Ln-transformed Chl & Ln-transformed TP \\
\hline $30-50$ & $-\mathbf{0 . 7 9 6}$ & $\mathbf{0 . 6 4 0}$ \\
$50-90$ & $-\mathbf{0 . 6 3 6}$ & -0.578 \\
\hline
\end{tabular}

between 4 and $20 \mathrm{mg} / \mathrm{L}$. Lastly, the seston was dominated by green algae and cyanobacteria, and Vanderploeg et al. (2009) showed that cyanobacteria can depress mussel feeding.

Similar to results reported by Vanderploeg et al. $(2001,2009)$ for studies done in the summer in Saginaw Bay and Lake Erie, we observed that clearance rates on Lake Michigan seston can be considerably lower than those observed for an ideal algal food like Cryptomonas. The particularly low value for September may have been related to the extremely low value of Chl observed at this time. In any event, the seston at this station was likely depleted by the mussels in light of the extremely large FC values seen for the 30-50 m depth zone and the low Chl values themselves. It is also possible that undesirable or inefficiently filtered algae left behind depressed the clearance rate (Vanderploeg et al., 2001, 2009). Fahnenstiel et al. (2010) noted a shift in dominance from diatoms to colonial cyanobacteria. The low clearance rate and the low $\mathrm{Chl}$ available at this time may indicate that further population growth is going to be constrained by food quantity and possibly food quality. The disappearance of $>53$-um size fraction is consistent with mussels consuming diatoms that were the normal dominants. This size fraction would likely have a slower growth rate than smaller size fraction because of surface-area constraints on growth (e.g. Reynolds, 1984) and therefore be more subject to consequences increased mortality. Unpublished results $(\mathrm{H}$. Vanderploeg) have shown that diatoms like Aulacoseira are readily ingested by the mussels.

\section{Connection of mussels to water column during winter-spring transition}

If the water column is not well mixed and currents are not sufficient to promote feeding and exchange water at the benthic boundary layer where mussels reside, our projections of clearance impacts in each of the depth zones will be overestimates (e.g. Ackerman, 1999; Ackerman et al., 2001; Widdows and Navarro, 2007). In a re-circulating flume Ackerman (1999) observed that a current speed of $9 \mathrm{~cm} / \mathrm{s}$ resulted in an optimal clearance rate for shallow-morph quagga mussels collected in Lake Erie for the current speeds examined. Clearance rates at lower current speeds ( 0.4 and $3.2 \mathrm{~cm} / \mathrm{s}$ ) were roughly $50 \%$ of that observed at $9 \mathrm{~cm} / \mathrm{s}$. At a current speed of $19 \mathrm{~cm} / \mathrm{s}$ the clearance rate was reduced to a value of $20 \%$ of that for the optimum speed. The latter response was a behavioral response related to the retraction of siphons seen at the higher speed. The maximum observed at $9 \mathrm{~cm} / \mathrm{s}$ may have been related to replenishment of algae at the boundary layer that did not occur at lower speeds (Ackerman, 1999). Later work with marine epifaunal bivalves (Cerastoderma edule, Mytilus edulis) indicates that they are adapted to feed with high clearance rate over a broad range of current speeds found in the environment to which they are adapted and for which they had previous experience (e.g. Widdows et al., 2002; Widdows and Navarro, 2007). In measurements of vertical profiles of algal cells in the deep flumes, speeds lower than $5 \mathrm{~cm} / \mathrm{s}$ with cockles (Cerastoderma edule) began to lead to depletion of cells near the benthic boundary.

As noted in Introduction conditions are isothermal and well mixed. Current speeds in Lake Michigan during winter are likely to encourage exchange of water near the bottom and be favorable to mussels, particularly in the southern basin of the lake, where speeds are 
somewhat higher than in the northern basin (Beletsky and Schwab, 2008: their Fig. 1). Most published information of currents in Lake Michigan during the winter-spring transition comes from reports of climatological mean seasonal vector-averaged flows or models of these flows (e.g. Rao et al., 2004; Beletsky and Schwab, 2008) or vector averaged flow for shorter time periods before, during, and after storm events (e.g. Beletsky et al., 2003). For Lake Michigan as a whole, depth averaged mean winter (November-April) current speed is $2.5 \mathrm{~cm} / \mathrm{s}$ and a maximum speed is $10.3 \mathrm{~m} / \mathrm{s}$. Speeds are somewhat lower in very nearshore and far offshore near the center of the basin (Rao et al., 2004; Beletsky and Schwab, 2008) Most of the flow is cyclonic and except during intense storms follows bathymetric contours. At the 38$\mathrm{m}$ depth in the SE corner of the lake (near St. Joseph, MI), measured seasonal averaged vector flows, nearly constant from top to bottom, ranged between 3.8 and $5 \mathrm{~cm} / \mathrm{s}$ for the 3 years studied (Rao et al., 2004). During storms instantaneous flows could be $20-50 \mathrm{~cm} / \mathrm{s}$. In the Muskegon region, where we collected our mussels, modeled winter circulation indicated flows approximately $8-10 \mathrm{~cm} / \mathrm{s}$ in middle depth regions (Beletsky and Schwab, 2008).

Instantaneous flows, which are what the mussel experience, are by definition higher on average than vector averaged seasonal flow and can be quite variable. No published information is available of time histories of instantaneous (hourly) near-bottom speeds for a long period of time during the winter spring transition. However, unpublished observations from current meters (N. Hawley, Great Lakes Environmental Research Laboratory) in waters near Muskegon during the winter of 1995 showed that instantaneous speeds were somewhat higher than the seasonal vector averaged results for the lake as a whole, and were quite variable. The instantaneous results also showed similar current speed from surface to $1 \mathrm{~m}$ above the bottom, which is strong signal of water column mixing. For January to May, hourly averaged mean \pm SD speeds were $10.3 \pm 5.8 \mathrm{~cm} / \mathrm{s}$ at the 58 -m depth contour, and $4.8 \pm 2.8 \mathrm{~cm} / \mathrm{s}$ at the $100-\mathrm{m}$ depth contour. At the $28-\mathrm{m}$ depth contour speeds were $4.4 \pm 2.8 \mathrm{~cm} / \mathrm{s}$ for JanuaryMarch, the only time for which information was available.

The dominant along-isobath component of currents during winter in Lake Michigan and the Great Lakes in general (Beletsky et al., 1999) means that onshore-offshore gradients in nutrients, other biogeochemical important materials, and productivity are likely to be maintained (Beletsky and Schwab, 2008) as has been observed in cross-isobath transects of sediment and nutrients ( e.g. Vanderploeg et al., 2007).

\section{Mussel filtering impacts in different depth zones}

As reported by Nalepa et al. (2010), mussel biomass has shifted more and more into deep water as quagga mussels replaced zebra mussels in shallow water and colonized deeper and deeper water. At the present time, maximum FC is found in the middle depth zone, 30$50 \mathrm{~m}$, where mussel biomass is greatest (Nalepa et al., 2010) and FC greatly exceeded the winter-spring benchmark growth rate of 0.06/ day and even light saturated maximum value of 012 /day. The ability of quagga mussels to colonize soft substrate has allowed expansion into deeper water, while at the same time the unstable (due to wave action) sandy substrate in shallow water prevents more extensive biomass build up there. Mussels on sandy substrate would be at particular risk during winter storms, when wave and current energy suspends sediment in much of the region shallower than $20 \mathrm{~m}$ (e.g. Vanderploeg et al., 2007). In rocky areas, however, particularly on the marl reefs and shorelines in certain areas the west side of Lake Michigan, hard substrate allows mussel colonization in shallow water. FC in the $30-50 \mathrm{~m}$ zone is much greater than in the $50-90 \mathrm{~m}$ zone, not only because of its greater mussel biomass but also because of the shallower water column depth.

The limited data available on mussel response to currents (Ackerman, 1999; Widdows and Navarro, 2007) would suggest that currents in 30 to $\sim 70 \mathrm{~m}$ depth region would be ideal for exchange at the boundary layer and promoting feeding; however, further work in this area in necessary. The profunda morph may be especially adapted to life at the boundary layer because of its long incurrent siphon which is typically more than half the length of the shell of the animal (Vanderploeg, unpublished observations). On soft substrates the animal lies with one valve in contact with the sediment, and the incurrent siphon is turned so that extends vertically upwards to take in water above the mussel.

The mid-depth sink-a new conceptual model for dreissenid impacts in deep lakes

The temporal patterns of Chl and TP coupled with the FC-depth pattern suggest that the mid-depth (30-50 $\mathrm{m}$ in Lake Michigan) zone acts as a sink for $\mathrm{Chl}$ and $\mathrm{P}$ removal and possible sequestration of $\mathrm{P}$ during isothermal conditions. Fahnenstiel et al. (2010) reported that there was an extreme drop in primary production at M110 during spring of 2007 and 2008 relative to observations made in 1983-1987 and 1995-1998. Likewise there were corresponding parallel changes in phytoplankton carbon and Chl. There was also a shift in importance of colonial cyanobacteria, which would be consistent with selective feeding by mussels. No other mechanism other than mussel selective feeding is consistent with these changes. No drops in depth integrated primary production, phytoplankton carbon, or Chl were seen during other seasons. These results are consistent with mussels being connected with the water column during the isothermal season and not connected during stratification.

The FC estimates clearly show there are not enough mussels at M110 or nearby to have a direct effect there; therefore, mussels in the $30-50 \mathrm{~m}$ and $50-90 \mathrm{~m}$ zones were likely affecting offshore Chl concentrations and primary production. Mussel distribution can be patchy but there was no major increase in mussel abundance in deep water near Muskegon. We hypothesize that mussels in the mid-depth zone were operating as a mid-depth $\mathrm{P}$ and $\mathrm{C}$ sink, particularly in the 30-50 m zone, intercepting $C$ and $P$ that would normally move from inshore to offshore (Fig. 4). This is consistent with the observations of Kerfoot et al. (2010) who observed that Chl and light transmittance on E-W cross-basin transects of the southern basin for April 2001, 2006, and 2008 showed a large drop in Chl and an increase in light transmittance in the mid-depth region and for some distance beyond

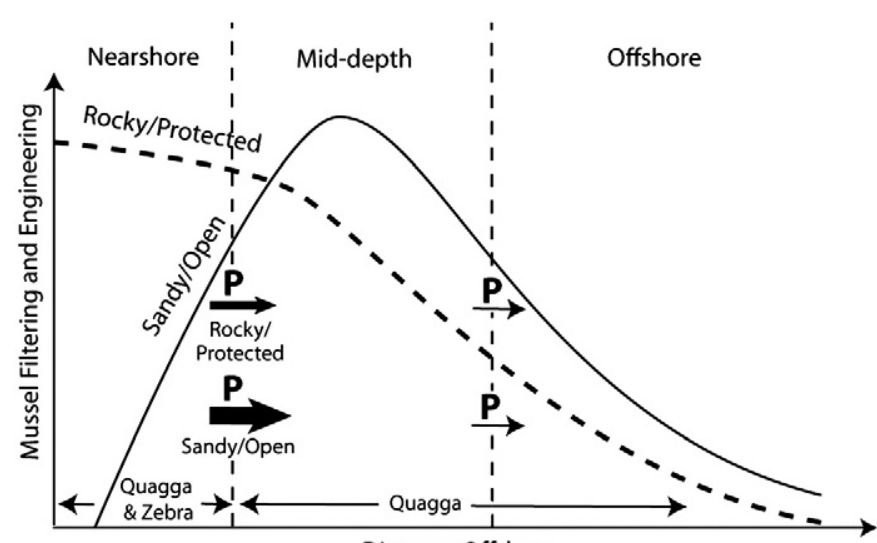

Distance Offshore

Fig. 4. Hypothetical effect of distribution of mussels on filtering (and ecosystem engineering) impacts and possible influence of movement of phosphorus ( $\mathrm{P}$ ) and carbon $(C)$ from nearshore to offshore zones having different substrates in the nearshore zones. In regions of the lake where there is no hard substrate for attachment of mussels in nearshore areas, mussels in the mid-depth region become important sink for nutrients, C, and particles moving from inshore to offshore areas. Whether mussels are abundant in the nearshore or mid-depth zone, delivery of P or C to the offshore zone delivery is likely to be reduced. 
the 100-m contour in 2006 and 2008. No changes were observed nearshore on the eastern side of the southern basin, which would be consistent with absence of mussels in the nearshore region.

Although the assumption of instantaneous mixing is clearly violated in the "basin-wide" estimate of FC because of slow transport across isobaths, its relatively large value is instructive in that a basinwide impact is implied. Also instructive is the large relative volume of water in the $>90 \mathrm{~m}$ depth zone (Table 4 ) which must be affected by the mussels to have an effect in the far offshore region. The results of Kerfoot et al. (2010) showing a lower Chl drop in the far offshore region than mid depth regions are consistent with the large volume of this zone and low abundance of mussels there.

Conceptually speaking, we may think of both a nearshore shunt (Hecky et al., 2004) and a mid-depth sink operating simultaneous in the same lake, and the dominance of the shunt or sink being defined by substrate and wave action (Fig. 4). In rocky protected regions, dreissenid mussel biomass would be associated with rocky substrate in the nearshore, and P loading would be sequestered in the nearshore region. In contrast, in sandy coastal areas such as the east side of the southern basin of Lake Michigan, wave action and sandy substrate prevent colonization by dreissenids, and the tributary loads and primary production that they stimulate move from inshore to middepth regions where they are first intercepted by mussels. The predominantly long-shore currents would aid in retention of $\mathrm{C}$ and $\mathrm{P}$ in the nearshore mid-depth regions.

The mid-depth sink is likely to be very important for Lake Michigan since $70 \%$ of the loading is associated with tributaries on the east side of the lake (Mida, 2010), and sand is the major substrate in nearshore areas of the east side of the lake. Major tributaries can be seen in Fig. 1. This loading and likely associated higher $\mathrm{Chl}$ and TP in the nearshore zone may partly explain the better condition of mussels found on the $25-\mathrm{m}$ depth contour than those found at M45 (Nalepa et al., 2010). Moreover, access of mussels to the full water column would be constrained for M45 mussels except in the isothermal period (e.g. Ackerman et al., 2001).

The mid-depth sink may be operating as well in other Great Lakes, as many have shallow sandy areas that are not suitable substrate for dreissenids. As in Lake Michigan, strong winter currents and alongbathymetric flow (Beletsky et al., 1999) would organize material transport (Vanderploeg et al., 2007; Beletsky and Schwab, 2008) and mussel impacts in the same way.

The ultimate distribution of mussels has not been established since populations are still expanding into deep water at the present time (Nalepa et al., 2010); however, it is possible that further expansion of high biomass of mussels into deep water will be constrained by the extremely low phytoplankton biomass and productivity (Fahnenstiel et al., 2010) and feedback between mussel population growth and feeding rate (Vanderploeg et al., 2009) that is already showing strong evidence of constraint. If so, the mid-depth sink will remain a permanent feature that will be a major force constraining phytoplankton production and the lower food web in Lake Michigan.

\section{Food web consequences and Diporeia}

The nearshore shunt and offshore sink offer plausible mechanisms for decreased productivity offshore of the regions mussels inhabit. The loss of the spring phytoplankton bloom noted by Fahnenstiel et al. (2010) and the lower concentration of some zooplankton (Kerfoot et al., 2010) are indications of emerging problems in the offshore planktonic food web. Loss of the benthic amphipod Diporeia, which is heavily dependent on the spring phytoplankton bloom, has been hypothesized to be caused by food limitation associated with expansion of the mussel populations (Nalepa et al., 2006). A problem with this hypothesis has been that Diporeia declined in regions offshore of the mussels as the mussel populations expanded. Although we cannot with any certainty say why Diporeia disappeared, the nearshore shunt and mid-depth sink mechanisms would be consistent with loss of Diporeia offshore of the expanding mussel populations.

\section{Future research}

The mid-depth sink hypothesis requires further evaluation especially with regard to how water motion and cross-isobath transport affect dispersion of mussel feeding and nutrient excretion impacts. The degree to which this mechanism is operating in other Great Lakes warrants examination. The effects of $\mathrm{P}$ and $\mathrm{N}$ excretion, both soluble and particulate excretion, need to be explored along with determining the degree to which mussel soft tissues and shells become a sink for P. It is likely that a full evaluation of such a hypothesis will require a spatially explicit model of nutrient movement from tributaries to offshore and a fully implemented primary production model containing mussel feeding and nutrient excretion processes.

We have focused our evaluation on the loss of the spring phytoplankton bloom and isothermal conditions. Evaluation of mussel impacts during summer presents particular challenges because of stratification and lower current speeds near the bottom may lead to incomplete and complex connections of the mussels with the water column above. Lastly, a bioenergetics model integrating the affects of changes in algal abundance is needed to understand the constraints that will ultimately define carrying capacity and spatial distribution of mussels.

\section{Acknowledgments}

We thank the crews of the R/V Shenehon and R/V Laurentian for help with collection of mussels and water and N. Morehead and S. Robinson for help with some experiments and analyses of chlorophyll. We thank N. Hawley for use of unpublished current meter data and N. Hawley and D. Beletsky for helpful comments on the manuscript.

\section{References}

Ackerman, J.D., 1999. Effect of velocity on the filter feeding of dreissenid mussels (Dreissena polymorpha and Dreissena bugensis): implications for trophic dynamics. Can. J. Fish. Aquat. Sci. 56, 1551-1561.

Ackerman, J.D., Loewen, M.R., Hamblin, P.F., 2001. Benthic-pelagic coupling over a zebra mussel reef in western Lake Erie. Limnol. Oceanogr. 46, 892-904.

Baldwin, B.S., Mayer, M.S., Dayton, J., Pau, N., Mendillo, J., Sullivan, M., Moore, A., Ma, A. Mills, E.L., 2002. Comparative growth and feeding in zebra and quagga mussels (Dreissena polymorpha and Dreissena bugensis): implications for North American lakes. Can. J. Fish. Aquat. Sci. 59, 680-694.

Beletsky, D., Schwab, D., 2008. Climatological circulation in Lake Michigan. Geophys. Res. Lett. 35.

Beletsky, D., Saylor, J.H., Schwab, D.J., 1999. Mean circulation in the Great Lakes. J. Great Lakes Res. 25, 78-93.

Beletsky, D., Schwab, D.J., Roebber, P.J., McCormick, M.J., Miller, G.S., Saylor, J.H., 2003. Modeling wind-driven circulation during the March 1998 sediment resuspension event in Lake Michigan. J. Geophys. Res.-Oceans 108.

Brooks, A.S., Torke, B.G., 1977. Vertical and seasonal distribution of chlorophyll a in Lake Michigan. J. Fish. Res. Board Can. 34, 2280-2287.

Bundy, M.H., Vanderploeg, H.A., Lavrentyev, P.J., Kovalcik, P.A., 2005. The importance of microzooplankton versus phytoplankton to copepod populations during late winter and early spring in Lake Michigan. Can. J. Fish. Aquat. Sci. 62, 2371-2385.

Fahnenstiel, G.L., Lang, G.A., Nalepa, T.F., Johengen, T.H., 1995. Effects of zebra mussel (Dreissena polymorpha) colonization on water quality parameters in Saginaw Bay, Lake Huron. J. Great Lakes Res. 21, 435-448.

Fahnenstiel, G.L., Stone, R.A., McCormick, M.J., Schelske, C.L., Lohrenz, S.E., 2000. Spring isothermal mixing in the Great Lakes: evidence of nutrient limitation and nutrientlight interactions in a suboptimal light environment. Can. J. Fish. Aquat. Sci. 57, $1901-1910$.

Fahnenstiel, G., Pothoven, S., Nalepa, T., Vanderploeg, H., Klarer, D., Scavia, D., 2010. Recent changes in primary production in the offshore region of southeastern Lake Michigan. J. Great Lakes Res. 36 (Supplement 3), 20-29.

Hecky, R.E., Smith, R.E.H., Barton, D.R., Guildford, S.J., Taylor, W.D., Charlton, M.N Howell, T., 2004. The nearshore phosphorus shunt: a consequence of ecosystem engineering by dreissenids in the Laurentian Great Lakes. Can. J. Fish. Aquat. Sci. 61, $1285-1293$.

Jones, H.D., Richards, O.G., Southern, T.A., 1992. Gill dimensions, water pumping rate and body size in the mussel Mytilus edulis L. J. Exp. Mar. Biol. Ecol. 155, 213-237.

Kerfoot, C.W., Foad, Y., Green, S.A., Budd, J.W., Schwab, D.J., Vanderploeg, H.A., 2010. Approaching storm: Disappearing winter bloom in Lake Michigan. J. Great Lakes Res. 36 (Supplement 3), 30-41. 
Kryger, J., Riisgard, H.U., 1988. Filtration-rate capacities in 6 species of European Freshwater bivalves. Oecologia 77, 34-38.

Lavrentyev, P.J., Gardner, W.S., Cavaletto, J.F., Beaver, J.R., 1995. Effects of the zebra mussel (Dreissena polymorpha Pallas) on protozoa and phytoplankton from Saginaw Bay, Lake Huron. J. Great Lakes Res. 21, 545-557.

Lei, J., Payne, B.S., Wang, S.Y., 1996. Filtration dynamics of the zebra mussel, Dreissena polymorpha. Can. J. Fish. Aquat. Sci. 53, 29-37.

MacIsaac, H.J., 1996. Potential abiotic and biotic impacts of zebra mussels on the inland waters of North America. Am. Zool. 36, 287-299.

Mida, J.L., Scavia, D., Fahnenstiel, G.L., Pothoven, S.A., Vanderploeg, H.A., Dolan, D.M. 2010. Long-term and recent changes in southern Lake Michigan water quality with implications for present trophic status. J. Great Lakes Res. 36 (Supplement 3), 42-49.

Nalepa, T.F., Fanslow, D.L., Foley III, A.J., Lang, G.A., Eadie, B.J., Quigley, M.A., 2006. Continued disappearance of the benthic amphipod Diporeia spp. in Lake Michigan: is there evidence for food limitation? Can. J. Fish. Aquat. Sci. 63, 872-890.

Nalepa, T.F., Fanslow, D.L., Pothoven, S.A., 2010. Recent changes in density, biomass, recruitment, size structure, and nutritional state of Dreissena populations in southern Lake Michigan. J. Great Lakes Res. 36 (Supplement 3), 5-19.

Rao, Y.R., McCormick, M.J., Murthy, C.R., 2004. Circulation during winter and northerly storm events in southern Lake Michigan. J. Geophys. Res.-Oceans 109.

Reeders, H.H., Bij DeVaate, A.B., 1990. Zebra mussels (Dreissena polymorpha)-a new perspective for water quality management. Hydrobiologia 200, 437-450.

Reynolds, C.S., 1984. The ecology of freshwater phytoplankton. Cambridge University Press.

Scavia, D., Fahnenstiel, G.L., 1987. Dynamics of Lake Michigan Phytoplanktonmechanisms controlling Epilimnetic Communities. J. Great Lakes Res. 13, 103-120.

Speziale, B.J., Schreiner, S.P., Giammatteo, P.A., Schindler, J.E., 1984. Comparison of N, Ndimethylformamide, dimethylsulfoxide, and acetone for extraction of phytoplankton chlorophyll. Can. J. Fish. Aquat. Sci. 41 (10), 1519-1522.
Strayer, D.L., Hattala, K.A., Kahnle, A.W., 2004. Effects of an invasive bivalve (Dreissena polymorpha) on fish in the Hudson River estuary. Can. J. Fish. Aquat. Sci. 61 924-941.

Strickland, J.D.H., Parsons, T.R., 1972. A practical handbook of seawater analysis, 2nd ed. Bull. Fish. Res. Bd. Can., 167 (310 pp)

Vanderploeg, H.A., Paffenhöfer, G.A., Liebig, J.R., 1988. Diaptomus vs. Net Phytoplanktoneffects of algal size and morphology on selectivity of a behaviorally flexible, omnivorous copepod. Bull. Mar. Sci. 43, 377-394.

Vanderploeg, H.A., Liebig, J.R., Carmichael, W.W., Agy, M.A., Johengen, T.H., Fahnenstiel G.L. Nalepa, T.F, 2001. Zebra mussel (Dreissena polymorpha) selective filtration promoted toxic Microcystis blooms in Saginaw Bay (Lake Huron) and Lake Erie. Can. J. Fish. Aquat. Sci. 58, 1208-1221.

Vanderploeg, H.A., Nalepa, T.F., Jude, D.J., Mills, E.L., Holeck, K.T., Liebig, J.R., Grigorovich, I.A., Ojaveer, H., 2002. Dispersal and emerging ecological impacts of Ponto-Caspian species in the Laurentian Great Lakes. Can. J. Fish. Aquat. Sci. 59, 1209-1228.

Vanderploeg, H.A., Johengen, T.H., Lavrentyev, P.J., Chen, C., Lang, G.A., Agy, M.A., Bundy, M.H., Cavaletto, J.F., Eadie, B.J., Liebig, J.R., Miller, G.S., Ruberg, S.A., McCormick, M.J. 2007. Anatomy of the recurrent coastal sediment plume in Lake Michigan and it impacts on light climate, nutrients, and plankton. J. Geophys. Res.-Oceans 112.

Vanderploeg, H.A., Johengen, T.H., Liebig, J.R., 2009. Feedback between zebra mussel selective feeding and algal composition affects mussel condition: did the regime changer pay a price for its success? Freshw. Biol. 54, 47-63.

Widdows, J., Navarro, J.M., 2007. Influence of current speed on clearance rate, algal cell depletion in the water column and resuspension of biodeposits of cockles (Cerastoderma edule). J. Exp. Mar. Biol. Ecol. 343, 44-51.

Widdows, J., Lucas, J.S., Brinsley, M.D., Salkeld, P.N., Staff, F.J., 2002. Investigation of the effects of current velocity on mussel feeding and mussel bed stability using an annular flume. Helgol. Mar. Res. 56, 3-12. 